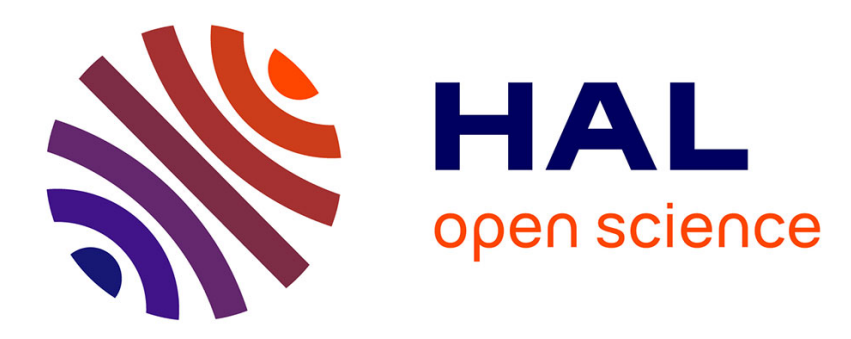

\title{
A single-phase photovoltaic Microinverter topology based on boost converter
}

\author{
Touhami Ternifi, Ghalem Bachir, Michel Aillerie
}

\section{To cite this version:}

Touhami Ternifi, Ghalem Bachir, Michel Aillerie. A single-phase photovoltaic Microinverter topology based on boost converter. Przeglad Elektrotechniczny , 2019, 1 (4), pp.215-217. 10.15199/48.2019.04.40 . hal-02152815

\section{HAL Id: hal-02152815 \\ https://hal.science/hal-02152815}

Submitted on 13 Jan 2021

HAL is a multi-disciplinary open access archive for the deposit and dissemination of scientific research documents, whether they are published or not. The documents may come from teaching and research institutions in France or abroad, or from public or private research centers.
L'archive ouverte pluridisciplinaire HAL, est destinée au dépôt et à la diffusion de documents scientifiques de niveau recherche, publiés ou non, émanant des établissements d'enseignement et de recherche français ou étrangers, des laboratoires publics ou privés. 


\title{
A single-phase photovoltaic Microinverter topology based on boost converter
}

\begin{abstract}
This paper presents a novel grid-connected photovoltaic Microinverter topology and its control implementation. A very significant contribution is to propose an innovative conversion structure with the aim of achieving high efficiency, easy control, high reliability and low design cost. In a first part of this contribution, we describe the proposed configuration topology. In a second part, we present the simulation tests developed in order to verify the validity and performance of its operating principle. The last part is reserved for discussion of the simulation results.

Streszczenie. W artykule opisano topologię mikroprzekształtnika współpracującego z ogniwem fotowoltaicznym. Zaproponowano nową koncepcję konwersji dla osiągnięcia prostego sterowania I małego kosztu. W pierwszej części opisano układ, w drugiej części przedstawiono wyniki symulacji a w trzeciej dyskusję wyników. Jednofazowy mikroprzekształtnik współpracujący z ogniwem fotowoltaicznym
\end{abstract}

Keywords: Photovoltaic Microinverter, Boost converter, PWM control, grid-connected

Słowa kluczowe: przekształtnik typu boost, ogniwo fotowoltaiczne

\section{Introduction}

In recent years, the grid-connected photovoltaic systems have attracted considerable interest in view of a crucial effect on improving their energy efficiency and reliability. With this in view, much research has focused on reducing costs and improving performance by modifying the power circuit topologies and the controller structures. In other words, the configuration of the photovoltaic panels and the right choice of the inverter have a direct influence on the cost and the efficiency of the whole system. On the market, there are three distinct types of photovoltaic systems: Type1- large-scale photovoltaic systems (generating several Megawatts) in regions with high solar insulation, Type 2- medium-scale PV systems (generating from one tenth to one hundredth of kilowatts), mainly for professional use and finally, Type 3- decentralized grid-connected photovoltaic systems on a small scale, such as photovoltaic structures based on Microinverters involved in small residential applications [1-3].

In Type 3, individual Microinverter connects a PV panel directly to the grid, adjusted to the maximum power thanks to an electronic tracker of this maximum point. Within this technological solution, the Maximum Power Point Tracker, MPPT [4, 5] allowing efficiency and improvement of the system reliability by eliminating the potential single point of failure $[1,6]$.

To this end in type 3 topology, photovoltaic Microinverters are the subject of extensive researches in academia and industry laboratories. Two important parameters in the design of Microinverters are considered, which are the quality of the injected signal into the grid and the sizing of the converter.

In the scope of this work, a compromise between the size of the Microinverter and the switching frequency need to be found. However, to maintain or improve efficiency at higher switching frequencies, advanced topologies and control strategies are needed [6-7]. Improving the Microinverter topology requires an optimal choice of power electronics, embedded devices and specialized microcontrollers for the driving of the power conversion and voltage adaptation processes [8].

The main objective of the presented study was to contribute to the improvement and the development of an efficient photovoltaic Microinverter using a new topology based on a boost converter with a reduced number of power switches allowing, after energy shape adaptation, direct injection into a distribution grid $[9,11]$.

As currently implemented with good performance in our laboratory, the developed Microinverter can be a low-cost alternative to isolated photovoltaic inverters that we found in the photovoltaic market $[9,10]$. To our knowledge, the simple structure of the boost topology and the switch control strategy has been never presented in literature. The described Microinverter topology in this article is presented for the first time.

This document is organized as follows. First, the general configuration of our circuit will be presented. In a second section, the operating mode of the proposed circuit will be described in order to foresee the suitable control technique. Finally, simulation waveforms will be provided and commented. The responses of the system will be commented in the last part and discussed for the validation of the various technological choices associated to this topology and the choice of electronic components used to build the Microinverter. Finally, will be presented conclusions and the perspectives of this work.

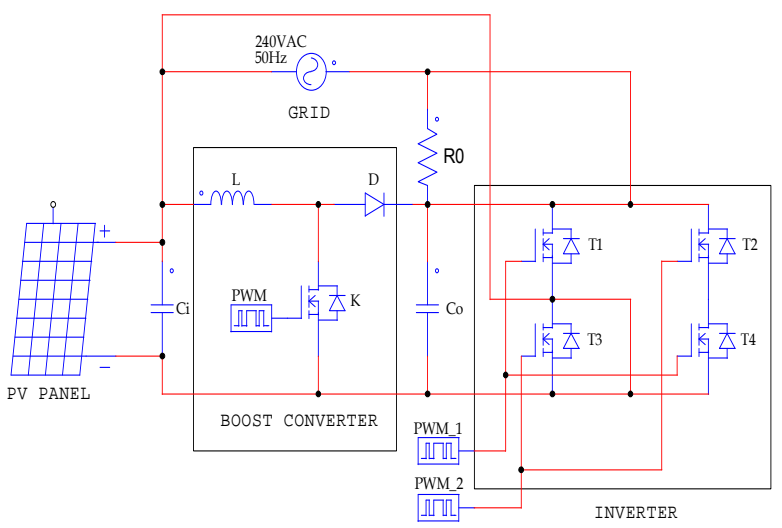

Fig. 1 Microinverter topology configuration

In Fig. 1, we present the Microinverter topology drawn using the PSIM software environment. It includes a boost converter and DC-AC inverter (conventional converter). In this structure, the boost converter is used to increase the input voltage to the required grid voltage value. However, by using an intelligent control strategy (such as the bipolar 
PWM), the inverter bridge converts the increased DC voltage to a sinusoidal waveform which will be filtered in order to inject it into the grid.

The Microinverters operating in this configuration are highly used by Schneider manufacturers (SunEzy 2000, 4000, 400E); SMA (Sunny Boy 2100TL) and AROS Sirio 4000 [7]. Different methods and techniques have been proposed to connect a solar panel to the grid via the Microinverter containing DC-DC and DC-AC converters [15].

For example, the approach that use the converting of DC voltage of the PV panel into a rectified full-waveform (Each period there are two half waves). Afterward, the bridge serves to keep the first one during the first half period and to reverse the second one during the other half period.

This approach is the most used in Microinverter flyback topologies (in all its configurations: interleaved, active clamp, ZVS using grid current, switched capacitor turn-off snubber) $[18,19]$. in our case, we propose a development of a simple and an original topology of the Microinverter based on a boost converter.

\section{Operating principle}

A circuit configuration of the proposed Microinverter consists in two parts, that can be operated and controlled independently as shown in Fig.2. First, the boost converter should generate a full rectified sine-wave. Second, the full bridge inverter controls the output current of the boost converter in order to obtain a sinusoidal current that is injected into the utility grid [20-22]. This injection can only be performed if the current is synchronized with the main current.

Thus, an advantage of the new proposed Microinverter shows that within this topology, the output electrical signal is generated in a self-regulating process. Details are presented and discussed in the following section, of our contribution.

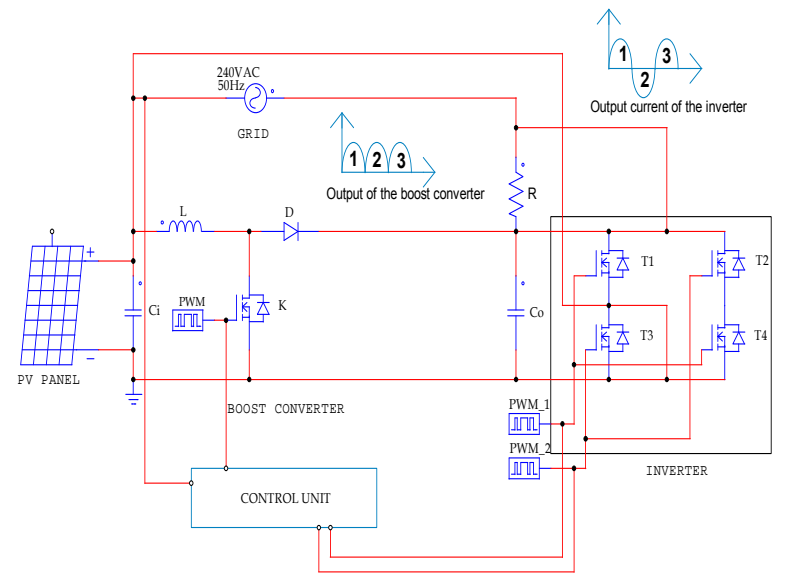

Fig.2. Microinverter operating diagram

\section{Results and discussion}

In order to have a more meaningful operation of our system, we performed the simulation with the PROTEUS software, using a PIC16F877A microcontroller. This gives us the opportunity to implement various programs into the control unit for the driving of the two stages. The Fig. 3 shows the complete electronic diagram of the proposed topology.

The operation can be described as follows: a serie of instructions are executed in order to generate the PWM signal, following the current supply by the grid (In figure 3 , the grid is represented by a VPULSE generator). To do this, we used the timer interrupt mode of the microcontroller (Timer2 register overflow) to ensure the reading of the current generated by the boost and to adjust the duty cycle PWM signal. An external interruption is also suggested (on the RB5 tab) to synchronize in a regular manner the variation of the two signals.

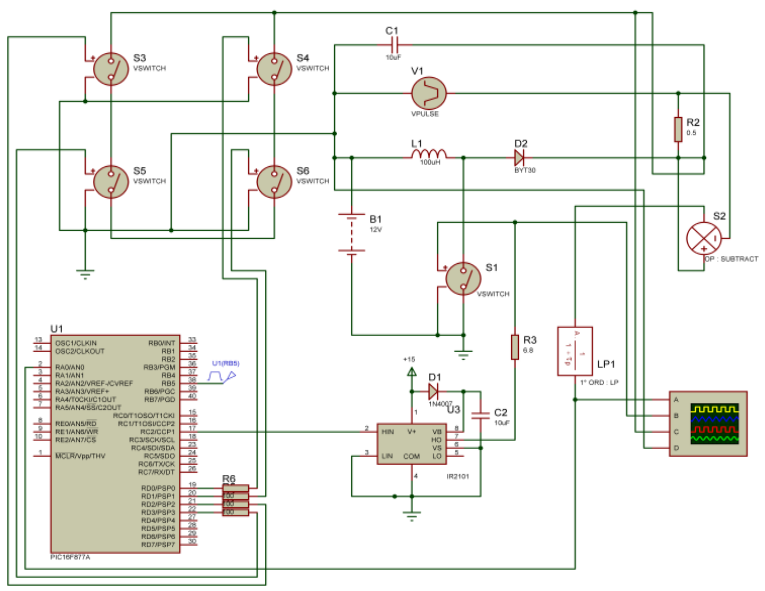

Fig.3.The simulation diagram

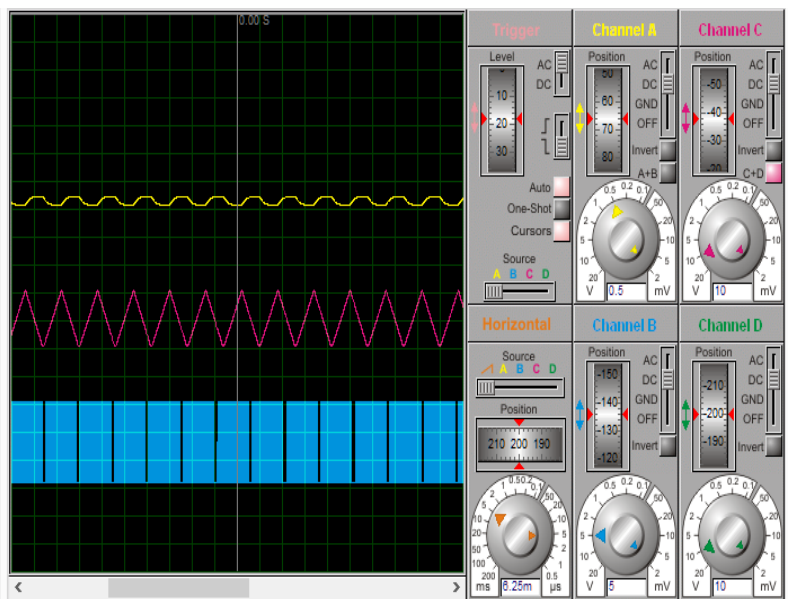

a) For low current

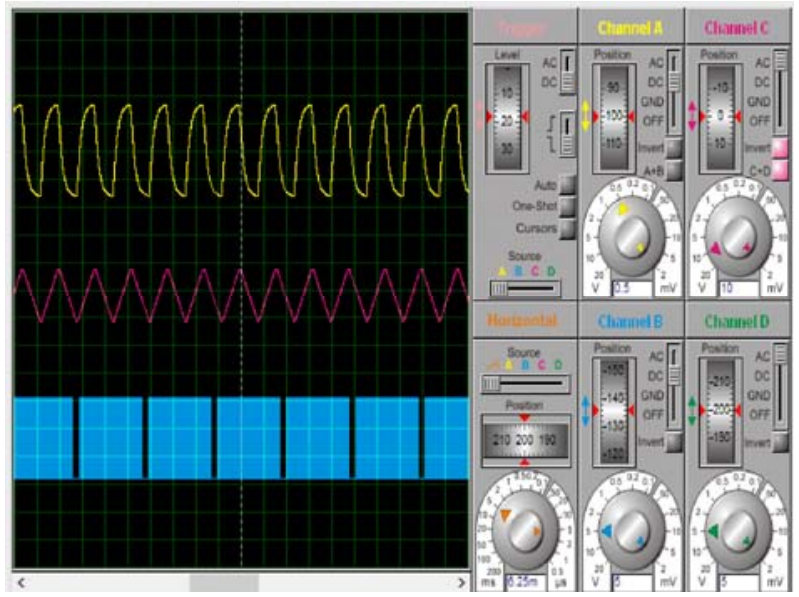

b) For nominal current

Fig. 4 The simulation results, a) for low current and b) for nominal current

As showen in figure 4 and in both cases, i.e. even for a low power given by the source, we observe that this topology allows the injection of a corresponding current into the grid. We also noticed that the shape of the output current of the microinverter is not purely sinusoidal (Fig. 4). This shape is not problematic for off-grid usages and can be 
improved to be the closest to a sinusoidal shape by adding a low-pass or a band pass filter centered at the grid frequency.

The obtained simulation results underly the validity of the developed model of this new microinverter topology. At this stage of the development and for off-grid applications, this microinverter can be directly implemented between a photovoltaic panel and an AC load. In addition, in a next step, for the on-grid applications, additional parameters for the PWM generation and filter will allow to obtain an output signal with a low harmonic distortion. In both cases, the integration of an algorithm for tracking of the maximum power point will be necessary to optimize the production efficiency by extracting the maximum available power available at the panel connectors

\section{Conclusion}

It can be concluded that in addition to many topology contributions for microinverters, they increase costs and decrease the efficiency of conversion. Future microinverters are expected to expand in response to technological advances in photovoltaic cells, semiconductor power devices, control circuits and grid integration standards. The topology proposed in this paper can satisfy several recommendations and challenges such as:

- The dual-stage conversion process will attract great attention because of its low cost, a longer life, and increased efficiency that could be reached with a compact structure.

- A compensation of harmonic, support grid voltage and frequency stability.

- The isurance of Galvanic isolation by optocouplers, the THD and the appropriate power factor rates that can be determined ensuringbetter reliability and grid compatibility.

The results of the simulation validate the originality of the topology based on the connection mode of the boost with the inverter bridge and the proposed method of control. In addition, this topology is able to enhance grid reliability and power quality. Hence, it can be clearly deduced that the main future research trends will be related to power decoupling methods, active power flow control, reactive power support in fault conditions and MPPT methods.

It is expected that this research will be of benefit for microinverter designers, researchers and engineers dealing with improvments of power conversion capability.

Authors. Touhami Ternifi, Ghalem Bachir, University of Science and Technology, MB of Oran, Faculty of Electrical Engineering, Durable Development of Electrical Energy Laboratory (LDDEE), E Mnaouar, BP 1505, Bir El Djir 31000, Oran, Algeria, E-mail: zineeddine.ternifi@univ-usto.dz, ghalem.bachir@yahoo.frl Michel Aillerie, optical materials, photonics and systems laboratory (LMOPS), EA 4423, University of Lorraine and Supelec, France, E-mail: aillerie@metz.supelec.fr.

\section{REFERENCES}

[1] Kim Y. S., Winston R., "Power conversion in concentrating photovoltaic systems: central, string, and microinverters,"Progress In Photovoltaics, Research And Applications, vol. 22, pp. 984-992, 2014.

[2] Islam M.R., Rahman F., Xu W., "Advances in Solar Photovoltaic Power Plants" (eBook) Springer, Green Energy and Technology, p13 and p215, 2016.

[3] Femia N., Granozio D., Petrone G., Spagnuolo G., Vitelli M.,"Optimized one-cycle control in photovoltaic grid connected applications," IEEE Transactions on Aerospace and Electronic Systems, vol. 42, Issue 3, Jul 2006.

[4] Selvan S., Nair P., Umayal, "A Review on Photo Voltaic MPPT Algorithms," International Journal of Electrical and Computer Engineering, Vol. 6, No. 2, pp. 567-582, Apr 2016.

[5] Khatib T., Azah M., A Reliable Maximum Power Point Tracker for Photovoltaic Systems, PRZEGLĄD
ELEKTROTECHNICZNY, Volume 90, Issue 11, 6 July 2006, Pages 1555-1578

[6] Wai R.J., Wang W.H.,"Grid-Connected Photovoltaic Generation System,"IEEE Transactions on Circuits and Systems I: Regular Papers, vol. 55, Issue: 3, April 2008.

[7] Pankow Y., "Etude de l'intégration de la production décentralisée dans un réseau basse tension : application au générateur photovoltaïque," Thesis, National Center of the Technological Research of Lille, 2004.

[8] Arab M., Zegaoui A., H. Allouache, Kellal M., Petit P., Aillerie M., "Micro-controlled Pulse Width Modulator Inverter for Renewable Energy Generators,"Energy Procediavol. 50,pp. 832-840, 2014.

[9] B. Gaiddon, T. Tran-Quoc, S. Bacha, C. Duvauchelle,"Projet ESPRIT - Typologie des onduleurs pour systèmes photovoltaïques," Etudes Scientifiques Prénormatives Sur Le Raccordement Au Réseau Electrique D'Installations Techniques Photovoltaïques, Déc 2010.

[10] K. Hemici, A. Zegaoui, A.A. Bokhtache, M.O. Mahmoudi, M. Aillerie,"Three-Phases Flying-Capacitor Multilevel Inverter with Proportional Natural PWM Control,"International Conference on Technologies and Materials for Renewable Energy, Environment and Sustainability, TMREES15 Energy Procedia, vol. 74, pp. 1061-1070, 2015.

[11] P. Petit, M. Aillerie, J.P. Sawicki, J.P. Charles,"Push-pull converter for high efficiency photovoltaic conversion,"Energy Procedia,vol. 18, pp. 1583-1592, 2012.

[12] S.M Islam, G.M Sharif, "Microcontroller based sinusoidal PWM inverter for photovoltaic application," IEEE First International Conference development in renewable energy technology, pp. 1-4, Dec 2009

[13] R.A. Mastromauro, M. Liserre, T. Kerekes, A. Dell'Aquila,"A Single-Phase Voltage-Controlled Grid-Connected Photovoltaic System With Power Quality Conditioner Functionality,"IEEE Transactions on Industrial Electronics, vol. 56, Issue 11, Nov. 2009.

[14] Y. Xue, L. Chang, S. B. Kjær, J. Bordonau, T. Shimizu,"Topologies of Single-Phase Inverters for Small Distributed Power Generators: An Overview,"IEEE Transactions on Power Electronics, vol. 19, No. 5, Sep 2004

[15] Jason C. Dominic,"Comparison and Design of High Efficiency Microinverters for Photovoltaic Applications,"Master Thesis, Virginia Polytechnic Institute and State University, Nov 14, 2014.

[16] TAN G., TANG Y., GAO B., FU X., JI Y., Soft-switching AC module inverter with flyback transformer for photovoltaic power system, PRZEGLAD ELEKTROTECHNICZNY, 88(10):180-184 - January 2012.

[17] Qian Zhang,"Optimization And Design Of Photovoltaic MicroInverter,"Thesis, B.S. Huazhong University of Science and Technology,2013.

[18] F. Edwin, X. Weidong and V Khadkikar, "Topology review of single phase grid-connected module integrated converters for PV applications," in Proc. IEEE IECON, pp.821-827, 2012.

[19] R. C. Variath, M. A. E. Andersen, O. N. Nielsen and A. Hyldgard, "A review of module invertertopologies suitable for photovoltaic systems," in Proc. IEEE IPEC, pp. 310-316, 2010.

[20] Gunjan Varshney, D. S. Chauhan, M. P. Dave, "Evaluation of Power Quality Issues in Grid Connected PV Systems," International Journal of Electrical and Computer Engineering, Vol. 6, No. 4, pp. 1412-1420, Aug 2016.

[21] Z. Touhami Ternifi, P. Petit, G. Bachir, M. Aillerie, "New Topology of Photovoltaic Microinverter Based on Boost Converter," International Conference on Technologies and Materials for Renewable Energy, Environment and Sustainability, TMREES17 Energy Procedia, vol. 119, pp. 938-944, 2017.

[22] Q. Ö. Çelika, A. Teke, A. Tan, "Overview of micro-inverters as a challenging technology in photovoltaic applications," Renewable and Sustainable Energy Reviews, vol. 82, Part 3, pp. 3191-3206, Feb 2018. 